\title{
Avaliação do processamento auditivo central em adolescentes expostos ao mercúrio metálico ${ }^{* * * *}$
}

\author{
Evaluation of central auditory processing in adolescents exposed to \\ metallic mercury
}

\author{
Marilene Danieli Simões Dutra* \\ Marcia Cavadas Monteiro** \\ Volney de Magalhães Câmara***
}

*Fonoaudióloga. Doutoranda em Saúde Coletiva pelo Instituto de Estudos de Saúde Coletiva da Universidade Federal do Rio de Janeiro.

Fonoaudióloga Servidora da Prefeitura da Cidade do Rio de Janeiro. Endereço para correspondência: Rua Marino da Costa, 104 - Apto 304 - Rio de Janeiro RJ - CEP 21940-210 (lenadutra@uol.com.br).

**Fonoaudióloga. Doutora em Distúrbios da Comunicação Humana pela Universidade Federal de São Paulo. Professora Adjunta do Curso de Fonoaudiologia da Universidade Federal do Rio de Janeiro.

***Médico. Doutor em Saúde Pública pela Fundação Oswaldo Cruz. Professor Titular da Faculdade de Medicina e Instituto de Estudos em Saúde Coletiva da Universidade Federal do Rio de Janeiro.

****Trabalho Realizado no Instituto de Estudos em Saúde Coletiva da Universidade Federal do Rio de Janeiro.

Artigo Original de Pesquisa

Artigo Submetido a Avaliação por Pares

Conflito de Interesse: não

\section{Abstract}

Background: central auditory processing and exposure to metallic mercury. Aim: to evaluate the performance on tests of central auditory processing in adolescents exposed to metallic mercury. Method: participants were 52 adolescents, of both genders, who presented hearing thresholds within normal limits. The study group (SG) was composed by 21 adolescents who worked on the burning of gold-mercury amalgams, on the re-burning of gold in stores that sell this metal or who lived next to gold mines or gold shops. The control group (CG) was composed by 31 adolescents who had no history of exposure to mercury. Investigation procedures included the application of a clinical, occupational and mercury exposure history questionnaire, basic audiometric assessment as well as central auditory processing tests. Results: Statistical significant differences in the auditory processing tests of non-verbal sound sequence memory test $(p=0,001)$, frequency pattern test $(p=0,000)$, duration pattern test $(p=0,000)$ and SSW test in Portuguese $(p=0,006)$ were observed between SG and CG. Conclusion: adolescents exposed to metallic mercury presented a lower performance on most of the auditory processing tests when compared to those who had no history of exposure to mercury. The main deficit found in the study was related to difficulty in distinguishing successive brief sounds.

Key Words: Auditory Perception; Mercury Poisoning; Adolescents.

\section{Resumo}

Tema: processamento auditivo central e exposição ao mercúrio metálico. Objetivo: comparar o desempenho nos testes comportamentais de processamento auditivo central entre adolescentes expostos e não expostos ao mercúrio metálico. Método: foram avaliados 52 adolescentes de ambos os sexos que apresentavam limiares auditivos dentro dos padrões de normalidade. O grupo de estudo (GE) incluiu 21 adolescentes que referiram trabalhar na queima dos amálgamas de ouro-mercúrio, re-queimar ouro em lojas que comercializam este metal ou residir próximos às áreas de garimpos e às lojas que comercializam ouro. O grupo de comparação (GC) foi composto por 31 adolescentes que não apresentaram história de exposição ao mercúrio. Os procedimentos incluíram um questionário sobre a história clínica, laboral e da exposição ao mercúrio, audiometria tonal liminar e bateria de testes para avaliação do processamento auditivo central. Resultados: As diferenças de desempenho na avaliação do processamento auditivo central entre o GE e o GC foram estatisticamente significantes para o teste de memória seqüencial para sons não verbais $(p=0,001)$, para os testes de padrão de freqüência $(p=0,000)$ e de duração $(p=0,000)$ e para o SSW em Português $(p=0,006)$. Conclusão: os adolescentes expostos ao mercúrio metálico apresentaram desempenho significativamente inferior aos não expostos para a maioria dos testes comportamentais do processamento auditivo central e a principal alteração encontrada nessa população foi no processamento de sons breves e sucessivos.

Palavras-Chave: Percepção Auditiva; Intoxicação por Mercúrio; Adolescente.

Recebido em 29.01.2009.

Revisado em 13.08.2009; 01.01.2010;

20.02.2010; 09.04.2010.

Aceito para Publicação em 01.09.2010. 


\section{Introduction}

Currently, more than 50 countries have areas of artisanal mining of gold. The metallic mercury, widely used in the processes of gold mining, may result in serious health hazards, exposing not only the individuals who work directly in mining but people living near these areas, especially children (1).

Concerns about the health problems caused by mercury have increased in recent years. Exposure to several forms of mercury can result in several adverse health effects (2). Among the major chronic effects of the presence of metallic mercury in the body, the damage to the central nervous system is highlighted (3). The toxicological effects of this metal are the most devastating ones for the development of central nervous system and for the overall physiological system of children and adolescents (4).

Study shows that exposure to heavy metals in children can affect regions of the central auditory nervous system and describes the correlation between levels of mercury in the blood and alterations in the central auditory processing skills (5). The findings from this study reinforce that the selection of the method of audiological evaluation of individuals exposed to mercury should consider tonal and speech audiometry as a starting point. However, the application of tests to assess the complete extent of the auditory system, such as electrophysiological and behavioral tests of central auditory processing, is necessary (6).

The central auditory processing (CAP) constitutes a series of processes involved in the detection and interpretation of sound events and is characterized by a set of specific auditory abilities $(7,8)$. The primary behavioral manifestation of individuals with central auditory processing disorders is the difficulty to listen and comprehend in noisy environment. A more broad understanding of the problem may aid on therapy guiding and on the development of preventive strategies (9).

The purpose of this study was to compare the performance in behavioral tests of central auditory processing of adolescents exposed and adolescents not exposed to metallic mercury enrolled in public schools in the city of Poconé/MT.

\section{Method}

This study was reviewed and approved by the Ethics in Research Committee of the Institute of Public Health Studies at the Federal University of Rio de Janeiro (Instituto de Estudos em Saúde Coletiva da Universidade Federal do Rio de Janeiro) under protocol number 88/2007. All participants and their parents and/or guardians signed a consent form and were informed about the research purpose and the procedures to be performed.

A cross-sectional descriptive study was performed with 57 adolescents. The procedures performed included questionnaire, otoscopy, pure tone audiometry, speech audiometry and assessment of the CAP.

The municipality of Poconé was selected for the study for two reasons. The first is that it is an area where gold extraction is still considered the most important economic activity for the city. The second is that studies developed in that area have demonstrated that local exposure to metallic mercury during the time of burning of gold-mercury amalgam does not only occurs at the site of gold mining, but also inside houses of residents (10), exposing workers and the general population to mercury.

The main biological indicator used to assess the level of metallic mercury is the urine test. However this level is related to recent exposure and although its use to monitor exposure to mercury vapors it is not a good indicator for assessing chronic exposures and accumulation of this substance in the central nervous system. The chronic effects of mercury exposure have been described in literature through data of exposure history and clinical signs and symptoms, or by autopsy studies (11).

Thus, for the present study, the groups were composed based on exposure history. Participants who reported working in the burning of goldmercury amalgam; or with gold re-burn at stores that commercialize this metal; or who resides close to mine areas and to shops that commercialize gold, composed the study group (SG). Participants who had no history of exposure to mercury composed the comparison group (CG).

As an inclusion criterion in the current study, participants had to be older than 12 years of age. Such criterion was set because the development of auditory processing occurs until that age, and thereafter is similar to that observed for adults (12). The maximum age of 17 years was established to avoid interference from other factors unrelated to exposure such as issues involving occupational risks. As an additional inclusion criterion, adolescents should have hearing sensitivity within normal limits.

Adolescents and their parents and/or guardians were subjected to a questionnaire concerning the development of speech, hearing and language; school records; behavioral characteristics; and specific questions about exposure to mercury and labor activities. 
To carry out the hearing assessments, an Interacoustic audiometer, model AC 33, with TDH MX-39 and pads 41, calibrated according to the ANSI-69 coupled to a CD player was used. The stimuli used for evaluation of CAP were recorded on CDs, Volumes 1 and 2, of the manual of central auditory processing assessment (13).

With the aim to evaluate the peripheral auditory system and to determine the hearing threshold, pure tone audiometry at frequencies from 250 to $8000 \mathrm{~Hz}$ and detection of speech recognition threshold were performed.

In order to evaluate the CAP, subjects underwent an assessment of listening skills through a special set of behavioral tests.

Three tests were conducted in open field: test of sound localization (SL) - that evaluated the ability to locate the sound source; and the tests of sequential memory for verbal (SMV) and nonverbal sounds (SMNV) - that aimed to evaluate the ability to temporally order sounds.

The speech test with white noise (SN) tested the auditory ability of closure and evaluated the discrimination of verbal sounds physically distorted. As verbal stimuli, a list of 25 monosyllabic words was ipsilaterally and simultaneously presented to white noise in a speech/noise ratio of $+5 \mathrm{~dB}$. The same words of the SN - in a different order of presentation - were used to research the percentage index of speech recognition (PISR). The percentages of correct responses in these tests were determined by the number of words correctly reproduced.

Temporal frequency (TFPT) and duration (DPT) pattern tests evaluated the auditory ability of temporal ordering (14). Sequences of three pure tones in six distinct orders were monaurally presented at an intensity level of $50 \mathrm{dBHL}$. Tones of the TFPT differ in frequency: $880 \mathrm{~Hz}$ and $1122 \mathrm{~Hz}$ (15) whereas tones of the DPT differ in duration: $500 \mathrm{~ms}$ and $250 \mathrm{~ms}$, with frequency maintained at $1000 \mathrm{~Hz}$.

The Staggered Spondaic Word Test (SSW) evaluates the hearing abilities of background figure, memory and temporal ordering of complex verbal sounds. The SSW test in Portuguese uses as sound stimuli paroxitone disyllabic words in Brazilian Portuguese, presented at $50 \mathrm{dBSL}$. There are 40 items consisting of four words - the first and fourth words are separately presented to each ear of the individual, whereas the second and third words are presented one to each ear simultaneously. Quantitative and qualitative analysis were performed for the results of this test.

The computer software SPSS 14 was used for statistical analysis. The descriptive statistics were used to characterize the sample profile according to the study variables, calculating the arithmetic mean and standard deviation for the continuous variables. The chi-square test for independence was applied and the adopted significance level was of $\mathrm{p}<0,05$. Statistically significant values were noted with an asterisk.

\section{Results}

After analyzing the criteria, 52 adolescents were included in the study. The study group comprised 21 adolescents, 11 females and 10 males. The mean age was 14 years and the mean threshold of frequencies of 500, 1000 and $2000 \mathrm{~Hz}$ in pure tone audiometry was $17.38 \mathrm{~dB}$ to right ear and $16.59 \mathrm{~dB}$ to the left ear. The comparison group was composed of 31 adolescents, 17 females and 14 males. The mean age was 14 years and the mean threshold of frequencies of 500, 1000 and $2000 \mathrm{~Hz}$ in pure tone audiometry was $16.99 \mathrm{~dB}$ to the right ear and 15.75 $\mathrm{dB}$ to the left ear. The mean age of both groups was 14 years with a standard deviation of 0.66 years, which demonstrates the homogeneity of the sample (Table 1).

Table 2 displays the between-groups comparison of performances in the open field tests. The mean score on the SMNV was 2.19 for SG and 2.81 for CG whereas the mean score for the SMV was 2.57 for SG and 2.77 for the GC. In the SL test, the two groups had an average of more than four hits.

Table 3 shows results of tests of CAP assessment. No between-groups differences were observed for the PISR and SN tests. In the TFPT, DPT, and SSW significant differences were observed when considering $\mathrm{p}<0.05$. 
TABLE 1. Characterization of adolescents from study group (SG) and control group (CG) according to age, gender and mean (in $\mathrm{dB}$ ) of hearing thresholds of pure tone audiometry at frequencies of 500,1000 and $2000 \mathrm{~Hz}$ (PTA).

\begin{tabular}{|c|c|c|c|c|c|}
\hline \multirow[b]{2}{*}{ Group } & \multirow[b]{2}{*}{ Sta tistics } & \multirow[b]{2}{*}{ Age } & \multirow[b]{2}{*}{ Gender } & \multicolumn{2}{|c|}{ PTA (mean 500Hz, $1 \mathrm{kHz}$ and $2 \mathrm{kHz})$} \\
\hline & & & & RE [dB] & LE [dB] \\
\hline \multirow[t]{2}{*}{ SG } & Mean & 14,29 & \multirow[t]{2}{*}{$\begin{array}{c}11-\mathrm{F} \\
10-\mathrm{M}\end{array}$} & 17,38 & 16,59 \\
\hline & $\begin{array}{c}\text { Standard Deviation } \\
\text { Minimum - Maximum }\end{array}$ & $\begin{array}{c}0,78 \\
13-16\end{array}$ & & $\begin{array}{c}2,39 \\
13,3-20,0\end{array}$ & $\begin{array}{c}2,33 \\
13,3-20,0\end{array}$ \\
\hline \multirow[t]{2}{*}{ CG } & Mean & 14,13 & \multirow[t]{2}{*}{$\begin{array}{l}17-\mathrm{F} \\
14-\mathrm{M}\end{array}$} & 16,99 & 15,75 \\
\hline & $\begin{array}{c}\text { Standard Deviation } \\
\text { Minimum - Maximum }\end{array}$ & $\begin{array}{c}0,56 \\
13-16\end{array}$ & & $\begin{array}{c}2,63 \\
11,7-21,7\end{array}$ & $\begin{array}{c}2,72 \\
8,3-20,0\end{array}$ \\
\hline \multirow[t]{2}{*}{$\begin{array}{l}\text { SG } \\
\text { CG }\end{array}$} & Mean & 14,19 & \multirow[t]{2}{*}{$\begin{array}{l}28-\mathrm{F} \\
24-\mathrm{M}\end{array}$} & 17,15 & 16,09 \\
\hline & $\begin{array}{l}\text { Standard Deviation } \\
\text { Minimum - Maximum }\end{array}$ & $\begin{array}{c}0,66 \\
13-16\end{array}$ & & $\begin{array}{c}2,52 \\
11,67-21,67\end{array}$ & $\begin{array}{c}2,58 \\
8,33-20,00\end{array}$ \\
\hline
\end{tabular}

TABLE 2. Mean, standard deviation, minimum and maximum values and p-values observed on the tests of verbal (SMV) and nonverbal (SMNV) sequential memory, and sound localization (SL) for study (SG) and control (CG) groups.

\begin{tabular}{ccccc}
\hline Grupo & Statistics & SMV & SMNV & SL \\
\hline \multirow{2}{*}{ SG } & Mean & 2,57 & 2,19 & 4,62 \\
& Standard Deviation & 0,60 & 0,68 & 0,67 \\
& Minimum - Maximum & $1-3$ & $1-3$ & $3-5$ \\
\hline \multirow{2}{*}{ CG } & Mean & 2,77 & 2,81 & 4,94 \\
& Standard Deviation & 0,43 & 0,40 & 0,25 \\
& Minimum - Maximum & $2-3$ & $2-3$ & $4-5$ \\
\hline \hline \multirow{2}{*}{ SG } & Mean & 2,69 & 2,56 & 0,81 \\
& Standard Deviation & 0,51 & 0,61 & $3-5$ \\
& Minimum - Maximum & $1-3$ & $1-3$ & 0,067 \\
\hline \hline
\end{tabular}

TABLE 3. Mean, standard deviation, minimum and maximum values and p-values for the behavioral tests - right ear (RE) and left ear (LE) - for study (SG) and control (CG) groups.

\begin{tabular}{|c|c|c|c|c|c|c|}
\hline Test & Group & Mean & SD & Minimum & Maximum & p-value \\
\hline \multirow{2}{*}{ PISR_R } & SG & 94,10 & 3,49 & 88 & 100 & \multirow{2}{*}{0,609} \\
\hline & CG & 95,10 & 3,22 & 92 & 100 & \\
\hline \multirow[b]{2}{*}{ PISR_L } & SG & 93,33 & 3,18 & 88 & 100 & \multirow[b]{2}{*}{0,191} \\
\hline & CG & 95,48 & 3,22 & 92 & 100 & \\
\hline \multirow{2}{*}{ SN_R } & SG & 87,24 & 4,12 & 80 & 92 & \multirow{2}{*}{0,228} \\
\hline & CG & 90,45 & 3,95 & 84 & 100 & \\
\hline \multirow{2}{*}{ SN_L } & SG & 88,19 & 3,89 & 84 & 96 & \multirow{2}{*}{0,613} \\
\hline & CG & 89,81 & 4,48 & 84 & 100 & \\
\hline \multirow{2}{*}{ TFPT_R } & SG & 52,14 & 9,37 & 40 & 80 & \multirow{2}{*}{$0,000 *$} \\
\hline & CG & 74,94 & 8,14 & 50 & 87 & \\
\hline \multirow{2}{*}{ TFPT_L } & SG & 49,05 & 9,70 & 33 & 74 & \multirow{2}{*}{$0,000 *$} \\
\hline & CG & 75,42 & 9,76 & 50 & 94 & \\
\hline \multirow{2}{*}{ DPT_R } & SG & 49,38 & 9,15 & 39 & 65 & \multirow{2}{*}{$0,000 *$} \\
\hline & CG & 77,55 & 8,71 & 56 & 91 & \\
\hline \multirow{2}{*}{ DPT_L } & SG & 50,38 & 11,44 & 27 & 76 & \multirow{2}{*}{$0,000 *$} \\
\hline & CG & 76,87 & 8,48 & 56 & 91 & \\
\hline \multirow{2}{*}{ SSW_R } & SG & 88,57 & 8,82 & 70 & 100 & \multirow{2}{*}{$0,006 *$} \\
\hline & CG & 95,25 & 4,34 & 77,5 & 100 & \\
\hline \multirow{2}{*}{ SSW_E } & SG & 88,93 & 7,77 & 72,5 & 100 & \multirow{2}{*}{$0,005 *$} \\
\hline & CG & 95,07 & 5,26 & 75 & 100 & \\
\hline \multirow{2}{*}{ Inversions } & SG & 2,90 & 3,51 & 0 & 11 & \multirow{2}{*}{0,000 * } \\
\hline & CG & 0,26 & 0,51 & 0 & 2 & \\
\hline
\end{tabular}

* p-value < 0,05; PISR - Percentage Index of Speech Recognition; SN - Speech in Noise ; TFPT - Frequen cy Pattern Test; DPT - Duration Pattern Test; SSW - Staggered Spondaic Word in Portuguese. 


\section{Discussion}

The evidences on occupational exposure to mercury are undeniable. However, its effects on the general population are still poorly explored. This is generally because the chemical pollutant poisoning occurs in a chronic manner and there is an absence of a classic clinical picture for most substances (16). Moreover, in adulthood, the relationships of cause and effect are difficult to be established because the exposure may not be remembered by the person who was exposed or might be masked by other diseases or confounding factors.

Thus, studies on exposure in childhood and adolescence are relevant for public health. Beyond being the population group most susceptible to adverse effects from exposure to heavy metals, such effects could be detected at sub-clinical stage and serve as an instrument in the monitoring of risk groups. The current study sought to contribute both to the reflection of this problem as to investigation of the correlation between CAP and mercury exposure, which results are described below.

All study participants had auditory thresholds within normal limits, considering the criterion of 25dBHL for frequencies from 250 to $8000 \mathrm{~Hz}$. This assessment was considered a criterion for inclusion in the study because tests used to evaluate CAP can be influenced by peripheral hearing loss (8).

This result is consistent with findings from the literature (17) which describes hearing thresholds within normal limits and evoked potential alterations increased latency between the peaks of waves III and $\mathrm{V}$. This indicates that the neurotoxic effect of mercury is more significant in the central auditory nervous system than in the peripheral level.

However, although in the present study the results of pure tone audiometry are within normal limits and have not shown significant differences between the two groups, a better performance of the CG was observed when compared to SG. A similar result was found in a study (18) that evaluated the effect of exposure to solvents in the CAP. That study found that the hearing thresholds of the exposed participants were higher than the ones of the comparison group.

Despite hearing complaints being often reported in individuals exposed to mercury, the hearing thresholds generally lie within the normal range or slightly altered. This reinforces the importance of tests that assess the auditory processing of such population.

Data analysis on the comparison of SG and CG regarding their performance in behavioral tests of auditory processing revealed a trend to a poorer performance of SG when compared to CG in all tests.
However, there were no statistically significant differences in the results obtained for SMV, SL (Table 2), PISR and SN tests (Table 3).

Statistically significant differences between the two groups were observed for SMNV, TFPT, DPT, SSW and the number of inversions made in the SSW test.

For the SMNV test, statistically significant differences $(p=0.001)$ between the two groups were observed, indicating that performance on auditory ability of temporal ordering of the SG was poorer than the CG (Table 2). Studies that investigated such ability in individuals exposed to metallic mercury were not found in the literature. However, similar results were found for individuals exposed to lead (19).

A hundred and fifty subjects (between 7 and 16 years) were evaluated in a study about the maturation effect on the behavior of tests of frequency and duration patterns (12). The percentages found for 14 year-olds were higher than 76\% in the TFPT and $72 \%$ in DPT. These values are similar to the ones found in this study for the CG. It is also observed that the percentage of correct responses was significantly lower in the SG (Table 3). These results corroborate with findings from studies that correlate the chemical exposure to changes in the ability of temporal ordering $(18,19,20)$.

Regarding the results of SSW, participants in the SG underperformed the participants from the CG (Table 3). This test assesses the background figure ability. Similar results were found in a study that evaluated the same ability in individuals exposed to solvents (18).

Analyzing the qualitative aspects of the SSW, a statistically significant difference in the number of inversions was observed in the comparison between SG and CG ( $(p=0.000)$ (Table 3). Despite the fact that no study that could be related to these results was found in the literature, it is emphasized that the auditory ability involving this task is the temporal ordering. Furthermore, other tests used in this study that evaluate such ability also showed statistically significant results.

Although studies that correlate CAP to exposure to metallic mercury had not been found in the literature, studies involving other chemicals such as solvents, lead and pesticides found results similar to the ones of the present study $(18,19,20)$.

The findings of the current study and of the studies previously cited are consistent with the finding that exposure to chemicals primarily affects the central auditory nervous system (6).

Although the pathophysiology of adverse health effects by chronic exposure to metallic mercury is not well defined, literature data show that among the main 
effects is the damage to the central nervous system, and among the structures affected are the substantia nigra, the occipital and temporal lobes. This last structure is of recognized importance for auditory processing. The auditory cortex is located in the temporal lobe and it is essential for the recognition of an organized succession of pure tones, frequencies or different durations as well for the recognition of complex sound patterns. Such correlation could explain the alterations found in the current study.

Thus, the adverse effects of chronic exposure to metallic mercury in the central nervous system appear to compromise the central auditory processing. However, studies on the effects of exposure to toxic substances, particularly the metallic mercury, on the central auditory system are still preliminary. This fact limits the comparison of the results of the current study with results of the literature. Further studies are necessary in order to better evaluate the effects of metallic mercury on central auditory system of

\section{References}

1.Bose-O'Reilly S, Lettmeier B, Gothe RM, Beinhoff C, Siebert U, Drasch G. Mercury exposure as a serious health hazard for children in gold mining areas. Environ Res. 2008;107:89-97.

2. Risher JF, Amler SN. Mercury exposure: evaluation and intervention - The inappropriate use of chelating agents in the diagnosis and treatment of putative mercury poisoning. Neurotoxicology. 2005;26:691-9.

3. World Health Organization. Inorganic mercury. Environmental health Criteria WHO, Geneva, Switzerland. $1991 ; 118$.

4. Counter SA, Buchanan LH. Mercury exposure in children: a review. Toxicol Appl Pharmacol. 2004;p.209-30.

5.Bamiou DE, Musiek LM, Luxon LM. Aetiology and clinical presentations of auditory processing disorders: a review. Arch Dis Child. 2001;85:361-5.

6. Morata TC. Chemical exposure as a risk factor for hearing loss. J Occup Environ Med. 2003;45:676-82.

7. Cavadas M, Pereira LD, Mattos P. Effects of methylphenidate in auditory processing evaluation of children and adolescents with attention deficit hyperactivity disorder. Arquivos de Neuro-Psiquiatria. São Paulo. 2007;65(1):138-43.

8. American Speech-Language-Hearing Association. (Central) Auditory Processing Disorders - The Role of the Audiologist [Position Statement]. 2005. Disponível em: www.asha.org/policy

9. Dawes P, Bishop DVM, Sirimanna T, Bamiou DE. Profile and aetiology of children diagnosed with auditory processing disorder (APD). Int J Pediatr Otorhinolaryngol. 2008;72:483-9.

10. Câmara VM, Tavares LMB, Filhote MIF, Malm O, Perez MA. A program for the control of indoor Pollution by metallic Mercury. Environ Res. 2000;83:110-6. individuals exposed to the impacts of gold production in Brazil.

\section{Conclusion}

Adolescents exposed to metallic mercury showed poorer performance than non-exposed adolescents in most tests. The differences between the performances of both groups were statistically significant for the non-verbal sequential memory test, frequency and duration pattern test, and the SSW test in Portuguese.

The main alteration found in the auditory processing of this population was on the perception of brief and successive sounds.

11. Faria MM. Mercuralismo metálico crônico ocupacional. Rev Saúde Pub. 2003;37:116-27.

12. Schochat E, Musiek FE. Maturation of outcomes of behavioral and electrophysiologic testes of central auditory function. J Commun Disord. 2006;39:78-92.

13. Pereira LD, Schochat E. Processamento auditivo central: manual de avaliação. São Paulo: Lovise; 1997.

14. Shinn JB. Temporal processing: the basics. Pathways Hear J. 2003;56:7.

15. Musiek FE. The frequency pattern test: A guide. Pathways Hear J. 2002;55:6.

16. Câmara VM, Tambellini AT. Considerações sobre o uso da epidemiologia nos estudos em saúde ambiental. Rev Bras Epidemiol. São Paulo. 2003(6)2.

17. Murata K, Weihe P, Budtz-Jorgensen E, Jorgensen PJ, Grandjea P. Delayed brainstem auditory evoked potential latencies in 14-year-old children exposed to methilmercury. J Pediatr. 2004;144:177-83.

18. Fuente A, Mcpherson B. Central auditory processing effects induced by solvent exposure. Int J Occup Med Environ Healt. 2007;20(3):271-9.

19. Jones L, Prins J, Park S, Walton JP, Luebke AE, Lurie D. Lead exposure during development results in increased neurofilament hosphorylation, neuritic beading, and temporal processing deficits within the murine auditory brainstem. J Comp Neurol. 2007;506:1003-17.

20. Fernandes TC. Exposição ocupacional aos inseticidas e seus efeitos na audição: a situação dos agentes de saúde pública que atuam em programas de controle de endemias vetoriais em Pernambuco [dissertação]. Recife: Centro de Pesquisas Aggeu Magalhães; 2000. 